NASA/TM-2000-209782
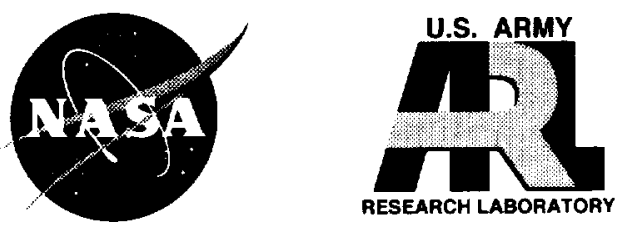

\title{
Load Capacity Estimation of Foil Air Journal Bearings for Oil-Free Turbomachinery Applications
}

Christopher DellaCorte

Glenn Research Center, Cleveland, Ohio

Mark J. Valco

U.S. Army Research Laboratory, Glenn Research Center, Cleveland, Ohio 
Since its founding, NASA has been dedicated to the advancement of aeronautics and space science. The NASA Scientific and Technical Information (STI) Program Office plays a key part in helping NASA maintain this important role.

The NASA STI Program Office is operated by Langley Research Center, the Lead Center for NASA's scientific and technical information. The NASA STI Program Office provides access to the NASA STI Database, the largest collection of aeronautical and space science STI in the world. The Program Office is also NASA's institutional mechanism for disseminating the results of its research and development activities. These results are published by NASA in the NASA STI Report Series, which includes the following report types:

- TECHNICAL PUBLICATION. Reports of completed research or a major significant phase of research that present the results of NASA programs and include extensive data or theoretical analysis. Includes compilations of significant scientific and technical data and information deemed to be of continuing reference value. NASA's counterpart of peerreviewed formal professional papers but has less stringent limitations on manuscript length and extent of graphic presentations.

- TECHNICAL MEMORANDUM. Scientific and technical findings that are preliminary or of specialized interest, e.g., quick release reports, working papers, and bibliographies that contain minimal annotation. Does not contain extensive analysis.

- CONTRACTOR REPORT. Scientific and technical findings by NASA-sponsored contractors and grantees.
- CONFERENCE PUBLICATION. Collected papers from scientific and technical conferences, symposia, seminars, or other meetings sponsored or cosponsored by NASA.

- SPECIAL PUBLICATION. Scientific, technical, or historical information from NASA programs, projects, and missions, often concerned with subjects having substantial public interest.

- TECHNICAL TRANSLATION. Englishlanguage translations of foreign scientific and technical material pertinent to NASA's mission.

Specialized services that complement the STI Program Office's diverse offerings include creating custom thesauri, building customized data bases, organizing and publishing research results... even providing videos.

For more information about the NASA STI Program Office, see the following:

- Access the NASA STI Program Home Page at $h t t p: / / w w w . s t i . n a s a . g o v$

- E-mail your question via the Internet to help@sti.nasa.gov

- Fax your question to the NASA Access Help Desk at (301) 621-0134

- Telephone the NASA Access Help Desk at (301) 621-0390

- Write to: NASA Access Help Desk NASA Center for AeroSpace Information 7121 Standard Drive Hanover, MD 21076 

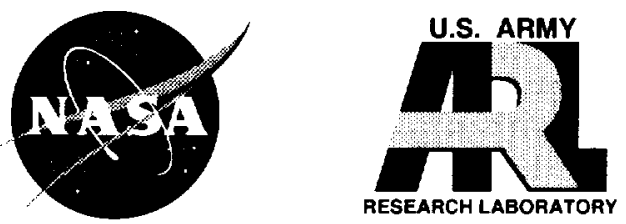

\section{Load Capacity Estimation of Foil Air Journal Bearings for Oil-Free Turbomachinery Applications}

Christopher DellaCorte

Glenn Research Center, Cleveland, Ohio

Mark J. Valco

U.S. Army Research Laboratory, Glenn Research Center, Cleveland, Ohio

Prepared for the

International Joint Tribology Conference

sponsored by the Society of Tribologists and Lubrication Engineers

Seattle, Washington, October 1-4, 2000

National Aeronautics and

Space Administration

Glenn Research Center 


\section{Acknowledgments}

The authors wish to express their sincere gratitude and appreciation to Dr. Hooshang Heshmat for his experience and historical insights in the field of foil bearings and for his assistance in recommending relevant reference materials.

Available from

NASA Center for Aerospace Information

7121 Standard Drive

Hanover, MD 21076

Price Code: A03
National Technical Information Service 5285 Port Royal Road Springfield, VA 22100 Price Code: A03

Available electronically at http://gltrs.grc.nasa.gov/GLTRS 


\title{
LOAD CAPACITY ESTIMATION OF FOIL AIR JOURNAL BEARINGS FOR OIL-FREE TURBOMACHINERY APPLICATIONS
}

\author{
Christopher DellaCorte \\ National Aeronautics and Space Administration \\ Glenn Research Center \\ Cleveland, Ohio 44135 \\ Mark J. Valco \\ U.S. Army Research Laboratory \\ National Aeronautics and Space Administration \\ Glenn Research Center \\ Cleveland, Ohio 44135
}

\section{SUMMARY}

This paper introduces a simple "Rule of Thumb" (ROT) method to estimate the load capacity of foil air journal bearings, which are self-acting compliant-surface hydrodynamic bearings being considered for Oil-Free turbomachinery applications such as gas turbine engines. The ROT is based on first principles and data available in the literature and it relates bearing load capacity to the bearing size and speed through an empirically based load capacity coefficient, D. It is shown that load capacity is a linear function of bearing surface velocity and bearing projected area. Furthermore, it was found that the load capacity coefficient, D, is related to the design features of the bearing compliant members and operating conditions (speed and ambient temperature). Early bearing designs with basic or "first generation" compliant support elements have relatively low load capacity. More advanced bearings, in which the compliance of the support structure is tailored, have load capacities up to five times those of simpler designs. The ROT enables simplified load capacity estimation for foil air journal bearings and can guide development of new Oil-Free turbomachinery systems.

\section{INTRODUCTION}

Foil air bearings are self-acting compliant-surface hydrodynamic bearings that use ambient air (or any process gas) as their working fluid or lubricant. By utilizing this Oil-Free technology, foil bearing supported turbomachinery can benefit from design simplicity and reduced weight (no oil system), high speed and temperature capability, and reduced maintenance. Foil bearings have proven themselves in relatively small lightly loaded applications, like aircraft air cycle machines (ACM's). Recent advances in foil air bearing design, high-temperature solid lubrication, and bearing and rotor system analytical modeling enable new applications in Oil-Free turbomachinery (ref. 1).

Foil air bearings were first commercialized in the 1970's in air cycle machines used for aircraft cabin pressurization (refs. 2 and 3). Since then, new applications in cryogenic turbo-expanders, turbo-alternators and turbochargers have been demonstrated (refs. 4 to 7 ). All of these applications relied on an experimental build and test development sequence. Although relatively time consuming and costly, this development approach is necessary due to the lack of accurate predictive performance analysis methods for a range of foil bearing sizes and designs. Despite the analytical and predictive shortcomings, experimental foil bearing characterization continues to add to the foil air bearing knowledge database. It is anticipated that as more applications are developed and ongoing research continues, an improved fundamental understanding of foil bearing performance characteristics will be developed to guide the engineering of new Oil-Free turbomachinery systems.

Three key technical hurdles have impeded the application and widespread use of foil air bearings beyond air cycle machines into other turbomachinery systems such as gas turbine engines. These technical hurdles are: (1) adequate load capacity, (2) high temperature start/stop lubricants and (3) reliable predictive performance methods and design guidelines.

Recent improvements in load capacity have been demonstrated. In a 1994 paper by Heshmat, a twofold increase in load capacity was reported (ref. 8). This improvement was attributed to the better design of the compliant foil structure based on elastic and hydrodynamic analytical modeling. Other researchers have indicated similar load 
capacity improvements but have not yet published the data in the open literature. These demonstrated levels of load capacity help remove the first technical hurdle.

High-temperature $\left(>300^{\circ} \mathrm{C}\right)$ bearing operation has always been a challenging technical hurdle because commonly used foil lubricant coatings rely on relatively low temperature materials (e.g., PTFE and $\mathrm{MoS}_{2}$ ) (refs. 5 and 9). These materials are used because, in addition to the good lubrication properties, they are flexible and as foil coatings they do not significantly alter the compliance and surface morphology of the top foil. These traditional solid lubricants are temperature limited to use under about $300^{\circ} \mathrm{C}$. Unfortunately, solid lubricants capable of operating above $300^{\circ} \mathrm{C}$ are relatively rigid ceramic-like materials that are difficult to apply and their presence significantly changes the compliance of the thin and flexible foil members (ref. 10 ).

Recent research on new high-temperature solid-lubricant coatings applied to bearing shafts (journals) appears to have overcome this second technical hurdle. Uncoated nickel-based superalloy foil bearings have been successfully lubricated with PS304 shaft coatings for over 100,000 start/stop cycles at temperatures as high as $650^{\circ} \mathrm{C}$ (refs. 1 and 7). PS304 is a plasma sprayed composite solid lubricant that has silver and fluoride eutectic lubricants in a metal/oxide matrix. During operation the lubricants transfer to the foils creating a thin but effective foil coating layer (ref. 1). By using PS304, or other similar coatings, high temperature operation with long life is achievable.

The third technical hurdle, reliable predictive performance methods and design guidelines has not yet been overcome. The reason for this shortfall is that foil bearings are inherently nonlinear and very difficult to model using relatively simplistic first principle methods (refs. 11 and 12). This modeling difficulty is due to the complex nonlinear structural, hydrodynamic fluid, and thermal interactions between the compliant foils and the fluid film which are often influenced by stick/slip frictional contacts between foil elements and the elastic foundation support structure (e.g., bumps) (ref. 13). In more technologically mature systems, such as rolling element bearings, extensive experimental data and application based experience has led to empirically based design guidelines (refs. 14 and 15). For air foil bearings, extensive experimental measurements have not been made, especially at high temperatures, and thus similar experience based guidelines are not yet available.

In this paper, an empirical or "Rule of Thumb" estimation of journal bearing load capacity is developed as an aid in feasibility assessments for foil bearing supported rotordynamic systems. The "Rule of Thumb" (ROT) is based on experimental data and fundamental first principles and is shown to be remarkably effective in making direct comparisons between bearing designs.

A similar ROT analysis of thrust foil bearings is inhibited by the lack of available thrust bearing load capacity data. Future work in this area is expected to result in a thrust foil bearing load capacity ROT following a research path that parallels the one reported in this paper.

Recognizing its limitations in scope and accuracy, the journal load capacity ROT serves as a first step for further work in developing similar ROT's for thrust bearing load capacity and for bearing dynamic (stiffness and damping) characteristics. The successful development of additional ROT's will help to overcome the third technological hurdle and foster the further successful application of foil air bearing technology to Oil-Free turbomachinery systems.

\section{FOIL BEARING BACKGROUND AND RULE OR THUMB DEVELOPMENT}

Foil air bearings operate under self-acting hydrodynamic principles in the same manner as conventional sleeve type rigid hydrodynamic bearings. However, a major difference is that foil bearings have compliant surfaces relative to rigid bearings; therefore, foil bearing geometry is not fixed. Figure 1 shows cross sections of two typical journal foil bearing designs, the overlapping leaf type foil bearing and the bump foil bearing. During operation, the hydrodynamic film pressure deflects or deforms the foils. The bearing geometry, therefore, is influenced by the operating conditions such as speed, load, and temperature.

At rest, the top (or inner) foil is spring preloaded against the shaft. There is no clearance as in a rigid sleeve bearing. As the shaft rotates, viscous air is circumferentially dragged in between the top foil surface and the shaft generating hydrodynamic pressure. This pressure acts upon the top (inner) foil causing it to separate from or "liftoff' the shaft surface and press against its compliant support structure. The fluid film pressure and foil compliance interact dynamically to seek an equilibrium state for a given set of conditions. Additionally, pressure changes in the shearing fluid film and viscous heating can lead to heat generation that may influence fluid film properties or foil mechanical properties. Because of these significant complex fluid/structural/thermal interactions, modeling of foil bearings must include fluid film and large deformation elastic effects.

From the perspective of load capacity, it is helpful to view the moving shaft surface as a viscous pump and the top foil as a smooth impermeable membrane seal that traps the gas film pressure. The gas film pressure that is 
generated is a function of the effectiveness of the pump and the efficiency of the foil to act as a seal. Foil bearing load capacity is the integration of the fluid film pressure across the foil surface area. Consequently, foil bearing load capacity is a complex function of bearing design and operating condition as are the bearing stiffness and damping characteristics.

On a fundamental first principles basis, the viscous pumping action of the shaft is proportional to surface velocity; therefore, the bearing diameter and rotational speed contribute to fluid film pressure and, hence, the bearing load capacity. The action of the foil is subtler. The foil surface must satisfy two seemingly conflicting requirements: maximize fluid film pressure and minimize leakage. In addition, local contact between the shaft and foil surfaces, i.e., high-speed rubs, must be avoided. This is accomplished by tailoring the foil support structure to provide a small but uniform fluid film thickness during operation taking into consideration that localized pressure decreases due to fluid leakage at the bearing edges.

Foil bearing load capacity defined here from an engineering viewpoint, is the maximum constant load that can be supported by a bearing operating with constant speed and steady-state conditions. Theoretically, as the minimum hydrodynamic film thickness decreases, the gas pressure increases suggesting perhaps that no distinct or discrete load capacity limit exists. In practice, however, when the nominal hydrodynamic fluid film thickness approaches the average surface (foil or shaft) roughness, asperity contact and rubbing occurs causing local frictional heating, wear and damage. Thus, the permissible or engineering load capacity is reached when the minimum fluid film thickness is somewhat greater than the average surface roughness of the bearing component.

Based upon these considerations, the permissible load that a bearing can support for a given working fluid is a function of design, bearing area and surface velocity. Put symbolically:

$$
\mathrm{W}=D(\mathrm{~L} \times \mathrm{D})(\mathrm{D} \times \Omega)
$$

Where:

$\mathrm{W}$ is the maximum steady-state load that can be supported, $\mathrm{N}$ (lbs)

$D$ is the bearing load capacity coefficient, $\mathrm{N} /\left(\mathrm{mm}^{3} \cdot \mathrm{krpm}\right)\left(\mathrm{lbs} /\left(\mathrm{in}^{3} \cdot \mathrm{krpm}\right)\right)$

$\mathrm{L}$ is the bearing axial length, $\mathrm{mm}$ (in.)

$\mathrm{D}$ is the shaft diameter, $\mathrm{mm}$ (in.)

$\Omega$ is the shaft speed in thousand $\mathrm{rpm}(\mathrm{krpm})$

This linear relationship should be reasonably accurate providing the fluid film is effectively incompressible with constant viscosity and the film thickness is nearly fixed (refs. 16 and 17). This is true for rigid gas bearings over a portion of their operating range as shown in figure 2 adapted from Faria and San Andres (ref. 17). In foil bearings the foils are purposefully designed to result in a near uniform film thickness across a broad operating range. In addition, since air viscosity, unlike many liquid lubricants, is a weak function of temperature a nearly linear relation between load capacity and surface velocity can be expected. In the above ROT, the empirically based load capacity coefficient, D, includes both fluid property and design effects.

For the ROT model presented, it is recommended that non-SI units (in. and lbs) be used as a mnemonic aid. By using these units it is observed that modern design foil air bearings typically support "a pound of load per inch of bearing diameter per square inch of bearing projected area per thousand rpm." While the authors clearly acknowledge that SI units are preferred, the units employed in using this Rule of Thumb (ROT) are easier to remember making the ROT more convenient. SI units will be used throughout this paper when discussing data and analysis and will be shown parenthetically with non-SI units where appropriate.

\section{EXPERIMENTAL DATA}

For foil journal bearings there is a growing body of experimental data on load capacity available in the literature (refs. 7, 8, 18 to 24). These references contain experimentally measured load capacity data for foil journal bearings ranging from 25 to $100 \mathrm{~mm}$ in diameter, operating over a wide speed and temperature range.

Performance data is summarized in table I and plotted in figures 3,5,7 to 9 . Figures 1,4 and 6 show representative bearing design details. It can be seen from the performance data that a nearly linear relationship exists between load capacity, surface velocity and projected area with the proportionally constant, D, which varies depending on bearing design. 


\section{DISCUSSION}

The limited foil bearing experimental data available is consistent with the linear approximation assumptions made in the ROT equation. By using the ROT, a direct comparison can be made between the performance (load capacity coefficients, D's) of different bearing designs operating at differing conditions.

The data in table I shows that the earliest bearings (from the 1960's and early 1970 's) had load capacity coefficient magnitudes, D 's, between about 0.1 and 0.3 . These early bearing designs, defined here as "first generation," had foil geometry's that were essentially uniform in both the axial and circumferential directions (including uniformly periodic circumferential geometry). Figure 1 shows some typical examples of "first generation" bearings. This means that the stiffness characteristics of the foil structure are also more or less uniform. Thus, in operation, the foil surface deforms due to the fluid film pressure without support structure specifically accounting for localized effects such as edge leakage, thermal gradients, heat generation and other hydrodynamic phenomena. The relatively simplistic features of these "first generation" air foil journal bearings enabled application to high-speed and lightly loaded systems. However these "first generation" bearings were also restricted by their inherent limitations in low overall pressure rise and local film thickness reductions leading to low load capacity.

For perspective it should be noted that "first generation" foil air bearings provided load capacities equivalent to circular, lobed or waved rigid gas bearings (refs. 22 and 25). Furthermore, these foil bearings provided greater damping, tolerance to misalignment and the ability to avoid high-precision manufacturing specifications and their associated costs.

During the 1970's and 1980's, through further research, additional levels of refinement were added to bearing designs enabling the purposeful tailoring of the stiffness characteristics of the foil support structure. These bearing designs, defined here as "second generation," are in commercial use in many air cycle machine applications. In these "second generation" bearings, the stiffness characteristics of the foil support structure typically vary either axially along the bearing length or in the circumferential direction, but not in both directions. Figure 4 shows some typical "second generation" bearing designs.

By controlling, the foil support stiffness in one dimension (axial or circumferential) the bearing can better accommodate physical phenomena like edge leakage and, hence, yield improved performance. In leaf foil bearings this design flexibility is provided through the use of a "stepped" backing spring that contacts the backside of the top foils during bearing operation (ref. 20). In bump type foil bearings, the bump layers are sometimes split circumferentially to allow axial control of compliance or the bump pitch can be varied to allow circumferential compliance control. A further design refinement reported is the use of soft metal (e.g., copper) coatings at the bump layer/top foil interface to enhance frictional damping and thermal conduction (ref. 23). Another design features a second smooth foil, which enhances performance (ref. 4).

Incorporating these "second generation" design features approximately doubled the bearing load capacity to coefficient magnitudes, $D$ 's, to the range of 0.3 to 0.6 . This level of performance represented substantial improvement over rigid gas bearing load capacity while retaining or further enhancing stiffness and damping characteristics. The enhanced performance resulted in successful commercial applications reported in the literature.

Bearing development and research completed to this point has demonstrated a degree in understanding of the intricate relationship between load capacity and the details of the foil support structure design. Namely, the ability to control and design the support structure compliance properties to enhance bearing load capacity. Additionally, the geometrical design features also influenced the amount of Coulomb damping that the bearing is capable of producing, although the damping process is not as well studied or quantified.

Advancements in foil bearings have continued the evolution into "third generation" foil bearing designs that tailor the foil support structure stiffness in axial (L), circumferential $(\theta)$ and radial (r) (i.e., displacement sensitive) directions to enhance performance even further (refs. 29 to 31). In 1993, Heshmat reported on a bearing design in which multiple bump layers, with spatially $(L, \theta, r)$ variable stiffnesses, are used to impart improved hydrodynamic, bearing stiffness and Coulomb damping properties (ref. 8). In this work, the calculated load capacity coefficient, D, has a magnitude of 1.4. This value is more than double that demonstrated a decade earlier and is the highest reported foil bearing load capacity the authors are aware of. Interestingly, the data reported for this bearing showed that damping and stiffness characteristics were also enhanced. The bearing design features described in the paper were matched with information available from the pertinent patents to produce the bearing illustration shown in figure 6 (refs. 29 and 8).

Recent work on "third generation" bearings includes high temperature $\left(650^{\circ} \mathrm{C}\right)$ load capacity tests on small bearings ( $25 \mathrm{~mm}$ length $\times 35 \mathrm{~mm}$ diameter) and room temperature tests on a large bearing (75 mm length $\times 100 \mathrm{~mm}$

diameter). Data from these tests have demonstrated bearing load capacity coefficient magnitudes, D's, around 1.0 (refs. 1 and 7). Figure 6 shows representative design features of these bearings in which the geometrical design has 
been tailored for the particular application (i.e., high temperature operation or large bearing size). Performance of these "third generation" bearings is shown in figures 7 to 9 .

Thus, despite significant changes in foil bearing support structural design, the simplified linear ROT introduced in this paper reasonably approximates bearing load capacity performance over the data range studied. It is expected that at extremely low speeds or high loads (e.g., the onset of film rupture) the model will not be accurate. However, for a "rule of thumb" engineering type analysis and application feasibility study, the ROT model for load capacity is a useful design guide.

Other important bearing parameters for rotor systems include stiffness and damping that must also be considered when assessing foil bearing feasibility for turbomachinery. These parameters directly influence rotordynamic stability and cannot be ignored. Foil bearing stiffness is derived from a combination of the fluid film compression and elastic deformation of the foil structure both with potentially substantial non-linearity. In contrast to the limited damping capability in rigid gas bearings, significant damping can and does occur in foil air bearings in both the fluid film (viscous effects) and in the foil support structure (Coulomb friction damping). Data in the literature as well as research underway at the author's laboratory suggests that advanced design bearings can provide adequate load capacity, damping and stiffness properties for many Oil-Free turbomachinery systems (ref. 6). Experimental results and theoretical analyses also suggest that load capacity performance can be "traded" for stiffness and damping enhancement through proper design compromises. Thus a bearing with excess load capacity for a given application can be tailored to provide better stiffness and damping at a lower load capacity (ref. 29). Because of this, further development of bearing load capacity remains an important research goal. With additional experimental and analytical work it may be possible to develop similar design ROT's for stiffness and damping characteristics of foil bearings.

\section{CONCLUSION}

This paper introduces the foil journal bearing load capacity estimation Rule of Thumb (ROT) concept. The experimental data published in the literature combined with experimental data collected at the author's laboratory was used to validate the ROT model. The enhancement of the load capacity coefficient magnitudes, $D$, over the last three decades can be correlated to the geometric details in the bearing foil support structures and the ability to tailor the design features to optimize bearing performance. With this concept in mind, it may be possible to assess or predict a foil bearing's performance potential based upon its design. Demonstrated improvements in bearing performance coupled with the development of suitable ROT's for thrust bearing load capacity, stiffness and damping will assist in the development of Oil-Free turbomachinery systems.

\section{REFERENCES}

1. DellaCorte, C., Lukaszewicz, V., Valco, M.J., Radil, K.C., and Heshmat, H.: "Performance and Durability of High Temperature Foil Air Bearings for Oil-Free Turbomachinery," NASA/TM-1999-209187.

2. Barnett, M.A., and Silver, A.: "Application of Air Bearings to High-Speed Turbomachinery," SAE Paper 700720, Sept. 1970.

3. Emerson, T.P.: "The Application of Foil Air Bearing Turbomachinery in Aircraft Environmental Control Systems," ASME Proceedings of the Intersociety Conference on Environmental Systems, San Diego, CA, July 10-13, 1978, Paper \#780-ENAS-18.

4. Agrawal, G.L.: "Foil Gas Bearings for Turbomachinery," Presented at $20^{\text {th }}$ Intersociety Conference on Environmental Systems, Williamsburg, VA, July 9-12, 1990, SAE Paper Number 901236, 1990.

5. O'Donner, L.: "Fluid-Film Foil Bearings Control Engine Heat," Mechanical Engineering, ASME, May 1993, pp. $72-75$.

6. Howard, S.A.: "Preliminary Development of Characterization Methods for Compliant Air Bearings." STLE Tribology Transactions, Vol. 42 (1999), 4, pp. 789-794.

7. DellaCorte, C.: "A New Foil Air Bearing Test Rig for Use to $700^{\circ} \mathrm{C}$ and $70,000 \mathrm{rpm}$," STLE Tribology Transactions, Vol. 41, \#3, 1998, pp. 335-340.

8. Heshmat, H.: "Advancements in the Performance of Aerodynamic Foil Journal Bearings High Speed and Load Capability," ASME Journal of Tribology, Vol. 116, pp. 287-295, April 1994.

9. Newman, P.: "Surface Coating for Machine Elements Having Rubbing Surfaces," U.S. Patent \#4,005,914, Feb. 1, 1977. 
10. Laskowski, J.A. and DellaCorte, C.: "Friction and Wear Characteristics of Candidate Foil Bearing Materials from $25^{\circ} \mathrm{C}$ to $800^{\circ} \mathrm{C}$," STLE Lubrication Engineering, Vol. 52, No. 8, pp. 605-612, 1997.

11. Arakere, N.K.: "Analysis of Foil Journal Bearings with Backing Springs," STLE Tribology Transactions, Vol. 39, No. 1, pp. 208-214, 1996.

12. Carpino, M., Peng, J.P., and Medvetz, L.: "Misalignment in a Complete Shell Gas Foil Journal Bearing," STLE Tribology Transactions, Vol. 37, No. 4, pp. 829-835, 1994.

13. Heshmat, C.A., Xu, D.S., and Heshmat, H.: "Analysis of Gas Lubricated Foil Thrust Bearings Using Coupled Finite Element and Finite Difference Methods," ASME Paper No. 99-TRIB-34, 1999.

14. Zaretsky, E.V.: "Life Factors for Rolling Element Bearings," STLE Special Publication.

15. Zaretsky, E.V., Poplowski, J.V., and Peters, S.M.: "Comparison of Life Theories for Rolling-Element Bearings," STLE Tribology Transactions, Vol. 32, No. 2, pp. 237-248, 1996.

16. Gross, W.A.: Gas Film Lubrication, John Wiley and Sons, Inc., 1962, p. 4.

17. Faria, M.T.C. and San Andres, L.: "On the Numerical Modeling of High Speed Gas Bearings," ASME paper 99-TRIB-2. Presented at the 1999 ASME/STLE Joint Tribology Conference, Kissamee, FL, Oct. 1999.

18. Ma, J.T.S.: "An Investigation of Self-Acting Foil Bearings," ASME, Journal of Basic Engineering, Dec. 1965, pp. 837-846.

19. Koepsel, W.F.: "Gas Lubricated Foil Bearing Development for Advanced Turbomachines," U.S. Air Force Report \#AFAPL-TR-76-114 Vol. 1, March 1977, p. 231.

20. Suriano, F.J.: "Gas Foil Bearing Development Program," U.S. Airforce Report \#AFWAL-TR-81-2095, September 1981.

21. Advanced Gas Turbine (AGT) Technology Development Project-Final Report, NASA CR-180891, December 1987. T. Strom Program Manager.

22. Ruscitto, D., McCormick, J., and Gray, S.: "Hydrodynamic Air Lubricated Compliant Surface Bearing for an Automotive Gas Turbine Engine - I - Journal Bearing Performance," NASA CR-135368, April 1978.

23. Heshmat, H., Shapiro, and W., Gray, S.: "Development of Foil Journal Bearings for High Lead Capacity and High Speed Whirl Stability," ASME Journal of Lubrication Technology, Vol. 104, No. 2, pp. 149-156, 1982.

24. Kirschmann, A.E., and Agrawal, G.L.: "High Temperature Foil Air Bearings Development for a Missile/UAV Engine Application," Proceedings of JANNAF Conference, Cleveland, Ohio, July 15-17, 1998.

25. Dimofte, F., Addy, H.E., and Walker, J.F.: "Preliminary Results of a Three Wave Journal Air Bearing," Proceedings of the Advanced Earth-to-Orbit Propulsion Technology Conference," NASA CP-3282, Vol. II, pp. 285-294, 1994.

26. Walton, J.F.: "Mohawk Innovative Technology Newsletter-Winter 1998," Mohawk Innovative Technology, Albany, NY, 1998.

27. Gray, S. and Bhushan, B.: "Support Element for Compliant Hydrodynamic Journal Bearings," U.S. Patent $\# 4,274,683$, June 1981.

28. Saville, M.P. and Gu, A.L.: "High Load Capacity Journal Foil Bearing," U.S. Patent \#5,116,143, May 1992.

29. Heshmat, H.: "High Load Capacity Compliant Foil Hydrodynamic Journal Bearing," U.S. Patent \#5,988,885, Nov. 1999.

30. Heshmat, H.: "A Feasibility Study on the Use of Foil Bearing in Cryogenic Turbopumps," Presented at the AIAA/SAE/ASME/ASEE $27^{\text {th }}$ Joint Propulsion Conference, June 24-26, 1991, Sacramento, CA, AIAA Paper No. 91-2103.

31. Bosley, R.W.: “Compliant Foil Hydrodynamic Fluid Film Radial Bearing," U.S. Patent \#5,427,455, June 1995. 
TABLE I.-PUBLISHED FOIL AIR JOURNAL BEARING LOAD CAPACITY DATA

\begin{tabular}{|c|c|c|c|c|c|c|}
\hline Bearing type & $\begin{array}{l}\text { Generation } \\
\text { number }\end{array}$ & Date & $\begin{array}{l}\text { Size, } \\
\operatorname{mm}(\text { in.) }\end{array}$ & $\begin{array}{c}\text { Speeds, } \\
\text { Krpm }\end{array}$ & $\begin{array}{l}\text { Load capacity } \\
\text { coefficient. }{ }^{2} \mathrm{D} \text {, } \\
\text { lbs/in. }{ }^{3} \cdot \mathrm{Krpm}\end{array}$ & References and comments \\
\hline $\begin{array}{l}\text { Tension dominated } \\
\text { tape type }\end{array}$ & $\mathbf{n} / \mathbf{a}$ & 1965 & $\begin{array}{l}\mathrm{L}=13(0.5) \\
\mathrm{D} \cong 50(2)\end{array}$ & to 14.4 & 0.016 & $\begin{array}{l}\text { Reference } 17 \text {, early magnetic tape } \\
\text { bearing }\end{array}$ \\
\hline $\begin{array}{l}\text { Rigid type circular } \\
\text { profile }\end{array}$ & $\mathbf{n} / \mathbf{a}$ & $\begin{array}{c}1977 \text { to } \\
1978\end{array}$ & $\begin{array}{l}\mathrm{L}=38(1.5) \\
\mathrm{D}=38(1.5)\end{array}$ & 5.10 .14 & $\Rightarrow 0.3$ & $\begin{array}{l}\text { Reference } 21 \text { not a foil bearing, } \\
\text { unstable above } 14 \mathrm{krpm}\end{array}$ \\
\hline $\begin{array}{l}\text { Rigid type wave } \\
\text { profile }\end{array}$ & $\mathrm{n} / \mathbf{a}$ & 1994 & $\begin{array}{l}\mathrm{L}=58(2.3) \\
\mathrm{D}=51(2.0\end{array}$ & 15 & $=0.24$ & $\begin{array}{l}\text { Reference } 24, \text { not a foil bearing, sta- } \\
\text { ble above } 15 \mathrm{krpm}\end{array}$ \\
\hline Leaf type & $1^{\text {st }}$ & $\begin{array}{c}1973 \text { to } \\
1976\end{array}$ & $\begin{array}{c}\mathrm{L}=150(6) \\
\mathrm{D}=114(4.5)\end{array}$ & $\begin{array}{l}20,23 \\
28,33\end{array}$ & 0.07 & $\begin{array}{l}\text { Reference } 18 \text {, early leaf type bearing } \\
\text { without backing springs, (US } \\
\text { Pat. } \# 3,215,479 \text { ) }\end{array}$ \\
\hline $\begin{array}{l}\text { Bump type } w / \text { single } \\
\text { bump layer }\end{array}$ & $1^{\text {st }}$ & $\begin{array}{c}1977 \text { to } \\
1978\end{array}$ & $\begin{array}{l}\mathrm{L}=38(1.5) \\
\mathrm{D}=38(1.5)\end{array}$ & $\begin{array}{l}30,45,55 \\
30,39,45\end{array}$ & $\begin{array}{c}0.3 @ 25^{\circ} \mathrm{C} \\
0.24 @ 315^{\circ} \mathrm{C}\end{array}$ & $\begin{array}{l}\text { Reference 21, simple bump foil bear- } \\
\text { ing. (US Pat. } \# 4,208,076 \text { ) }\end{array}$ \\
\hline $\begin{array}{l}\text { Bump type } w / \text { single } \\
\text { bump layer }(\mathrm{Cu} \\
\text { coated })\end{array}$ & $1^{\text {st }}$ & 1980 & $\begin{array}{l}\mathrm{L}=44(1.7) \\
\mathrm{D}=35(1.4)\end{array}$ & to 40 & 0.43 & Reference 22. (US Pat. $\# 4.277,113$ ) \\
\hline $\begin{array}{l}\text { Leaf type w/backing } \\
\text { springs }\end{array}$ & $2^{\text {nd }}$ & $\begin{array}{l}1979 \text { to } \\
1981\end{array}$ & $\begin{array}{l}\mathrm{L}=107(4.2) \\
\mathrm{D}=89(3.5)\end{array}$ & 12.33 .2 & $\begin{array}{l}0.4 @ 25^{\circ} \mathrm{C} \\
0.3 @ 500{ }^{\circ} \mathrm{C}\end{array}$ & $\begin{array}{l}\text { Reference } 19, \text { load capacity at } 25^{\circ} \mathrm{C} \\
\text { may be higher, (US Pat. } \# 4,153.315 \text { ) }\end{array}$ \\
\hline $\begin{array}{l}\text { Leaf type w/backing } \\
\text { springs }\end{array}$ & $2^{\text {nd }}$ & $\begin{array}{c}1979 \text { to } \\
1987\end{array}$ & $\begin{array}{l}\mathrm{L}=27(1.1) \\
\mathrm{D}=34(1.4)\end{array}$ & 75,100 & 0.06 to 0.2 & $\begin{array}{l}\text { Reference } 20 \text {. bearings not optimized } \\
\text { for maximum load capacity }\end{array}$ \\
\hline $\begin{array}{l}\text { Bump type w/single } \\
\text { bump layer }(\mathrm{Cu} \text { coated } \\
\text { and circumferentially } \\
\text { split) }\end{array}$ & $2^{\text {nd }}$ & 1982 & $\begin{array}{l}\mathrm{L}=44(1.7) \\
\mathrm{D}=35(1.4)\end{array}$ & to 68 & 0.50 & Reference 22. (US Pat. \#4.277.112) \\
\hline $\begin{array}{l}\text { Bump type reverse } \\
\text { multiplayer twin top } \\
\text { foils and single bump } \\
\text { layer }\end{array}$ & $2^{\text {nd }}$ & 1998 & $\begin{array}{l}\mathrm{L}=40(1.6) \\
\mathrm{D}=40(1.6)\end{array}$ & to 55 & $\begin{array}{c}\approx 0.6^{\mathrm{b}} \\
\text { (estimated) }\end{array}$ & $\begin{array}{l}\text { Reference 23, bearing tested with } \\
\text { dynamic load, (US Pat. } \# 4,414,280 \text { ), } \\
\text { (US Pat. } \# 4,414,281 \text { ) }\end{array}$ \\
\hline $\begin{array}{l}\text { Bump type w/multiple } \\
\text { bump layers. split } \\
\text { circumferentially and } \\
\text { axially }\end{array}$ & $3^{\text {rd }}$ & 1994 & $\begin{array}{l}\mathrm{L}=31(1.2) \\
\mathrm{D}=35(1.4)\end{array}$ & $\begin{array}{l}29.7 .50 \\
59.7\end{array}$ & 1.4 & $\begin{array}{l}\text { Reference } 8 \text {, bearing optimized for } \\
\text { load capacity, (US Pat. \#4.300.806) }\end{array}$ \\
\hline $\begin{array}{l}\text { Bump type w/single } \\
\text { top foil. staggered } \\
\text { bump foil (split axially } \\
\text { and circumferentially) }\end{array}$ & $3^{\text {dd }}$ & 1998 & $\begin{array}{l}\mathrm{L}=27(1.1) \\
\mathrm{D}=35(1.4)\end{array}$ & 5 to 40.0 & $\begin{array}{c}0.8 \text { to } 1.0 \\
\text { @ } 25 \text { to } 650^{\circ} \mathrm{C}\end{array}$ & $\begin{array}{l}\text { Reference } 7 \text {, shaft coated with slightly } \\
\text { porous high temperature lubricant. } \\
\text { (US Pat. } \# 5,902,049 \text { ) }\end{array}$ \\
\hline $\begin{array}{l}\text { Bump type w/stag- } \\
\text { gered bump foil (large } \\
\text { bearing) }\end{array}$ & $3^{\text {rd }}$ & 1998 & $\begin{array}{l}\mathrm{L}=76(3.0) \\
\mathrm{D}=102(4.0)\end{array}$ & $10.22,30$ & 0.8 & $\begin{array}{l}\text { Reference } 25 \text {, bearing design for large } \\
\text { size. (US Pat. } \# 5,988.885 \text { ) }\end{array}$ \\
\hline
\end{tabular}

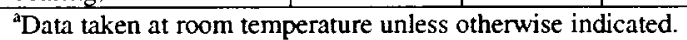

${ }^{b}$ Bearing tested with $10 \mathrm{~N}$ static load plus an additional $600 \mathrm{~N}$ imbalance load. 

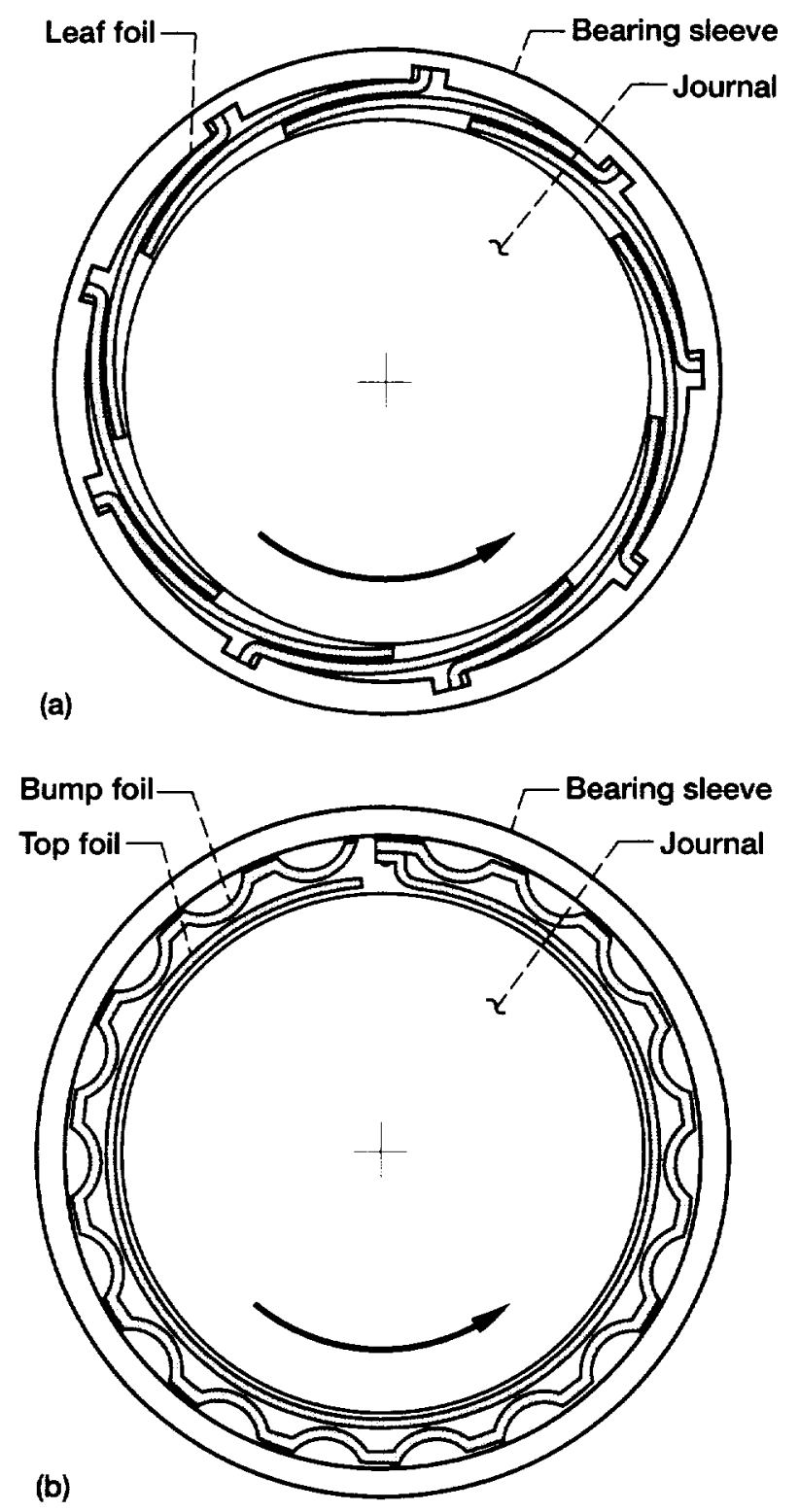

Figure 1.-Schematic example of first generation foil bearings with axially and circumferentially uniform elastic support elements. (a) Leaf-type foil bearing. (b) Bump-type foil bearing. 


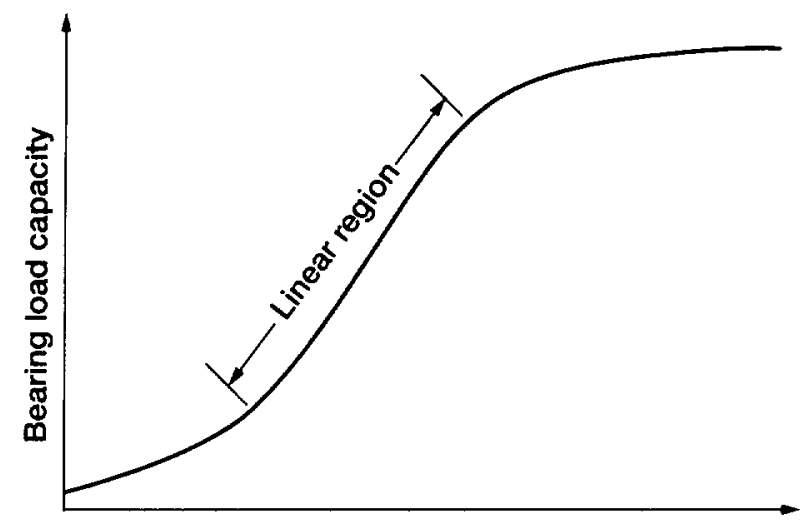

Bearing number (surface velocity)

Figure 2.-Non-dimensionalized, theoretical load capacity for circular rigid gas bearing. Adapted from Faria and San Andres reference 17.

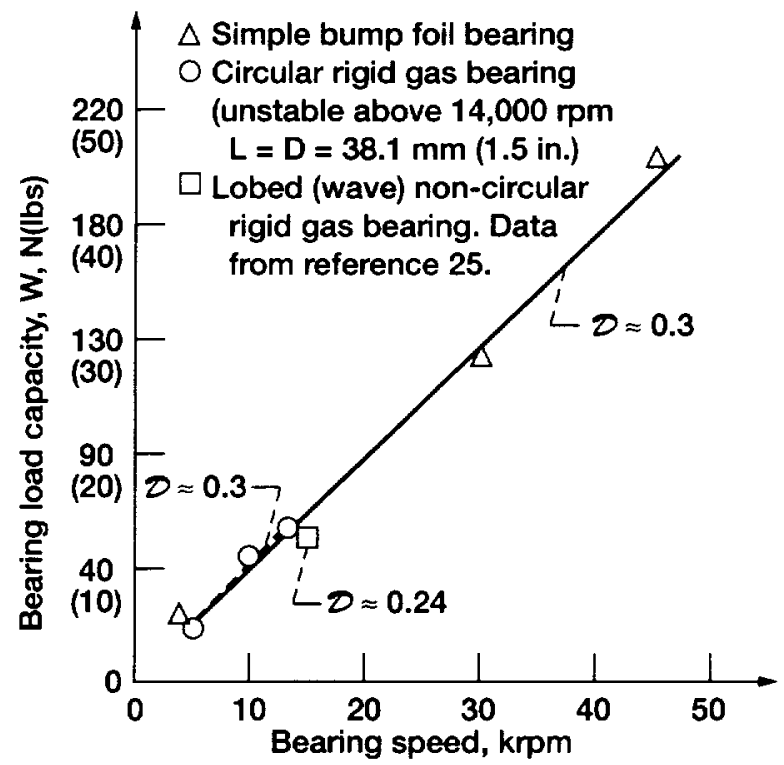

Figure 3.-Foil bearing load capacity for first generation bump foil type bearing at $25^{\circ} \mathrm{C}$. Data from reference 21. 


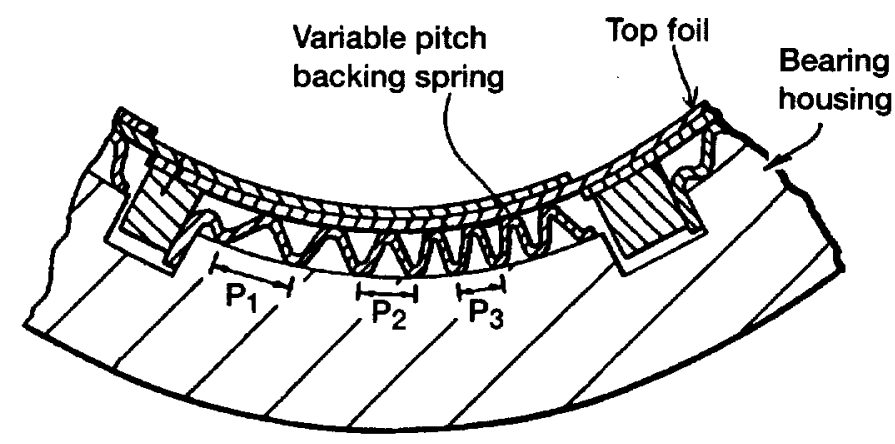

(a)
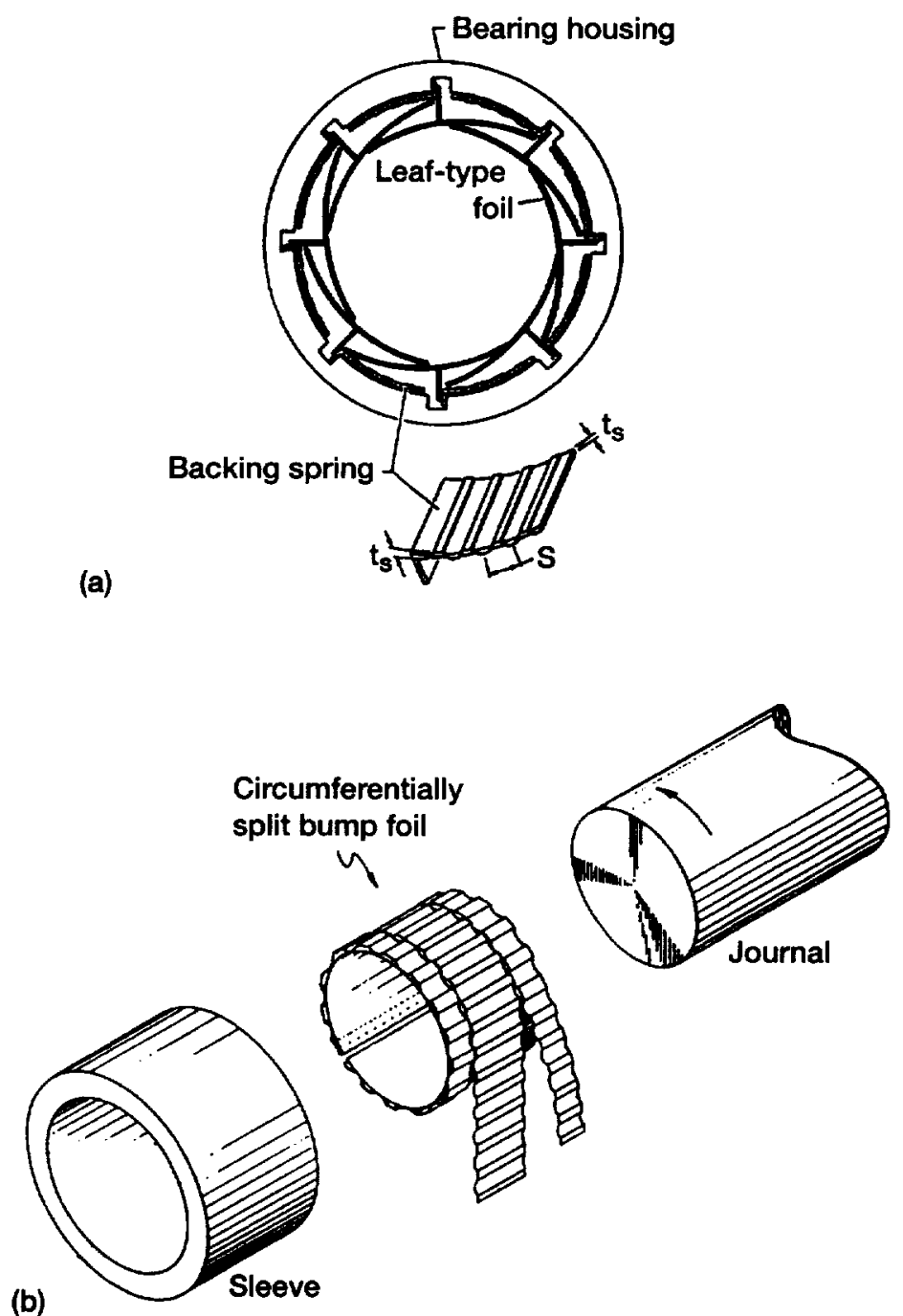

Figure 4.-Selected details illustrating elastic support components of second generation foil air bearings offering variable circumferential or axial compliance characteristics. (a) Variable pitch backing springs, references 11 and 28. (b) Circumferentially split bump foil, reference 27 . 


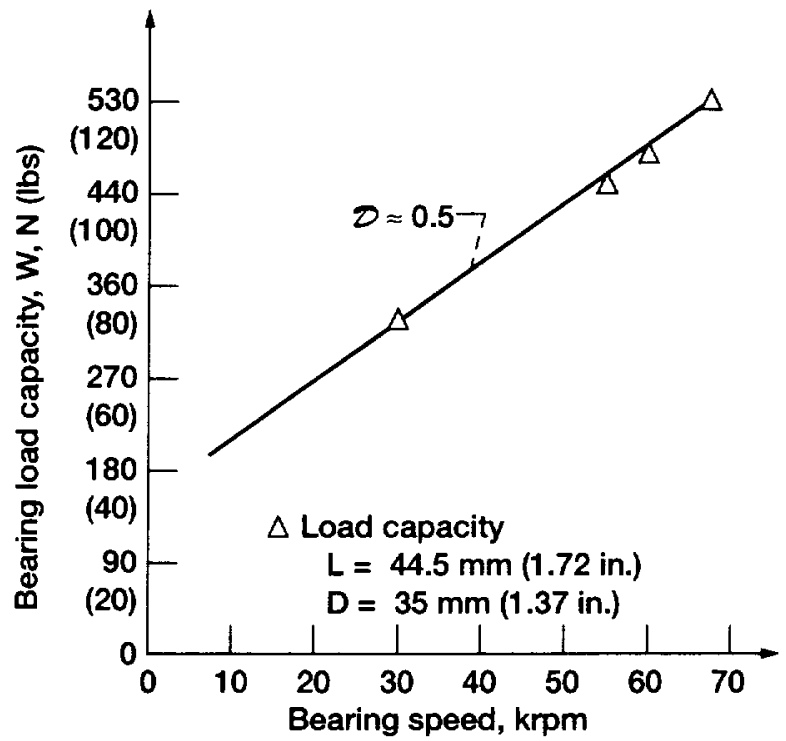

Figure 5.-Foil bearing load capacity for second generation bump foil bearing having a single circumferentially split bump foil. Data from reference 23 . 

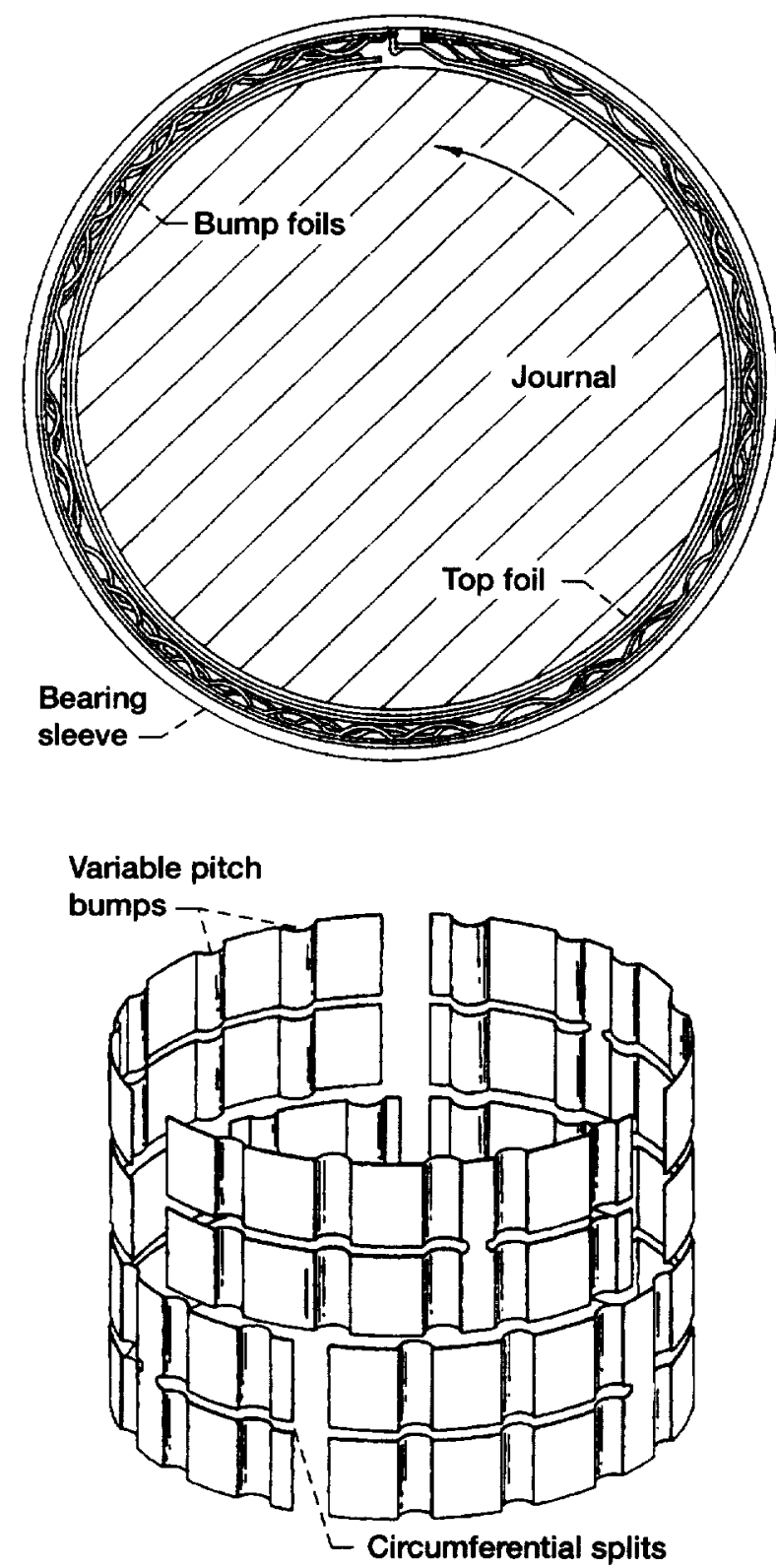

Figure 6.-Selected details of third generation foil air bearings elastic support mechanisms which allow both axial and circumferential tailoring of compliance. Bump foil from reference 29. 


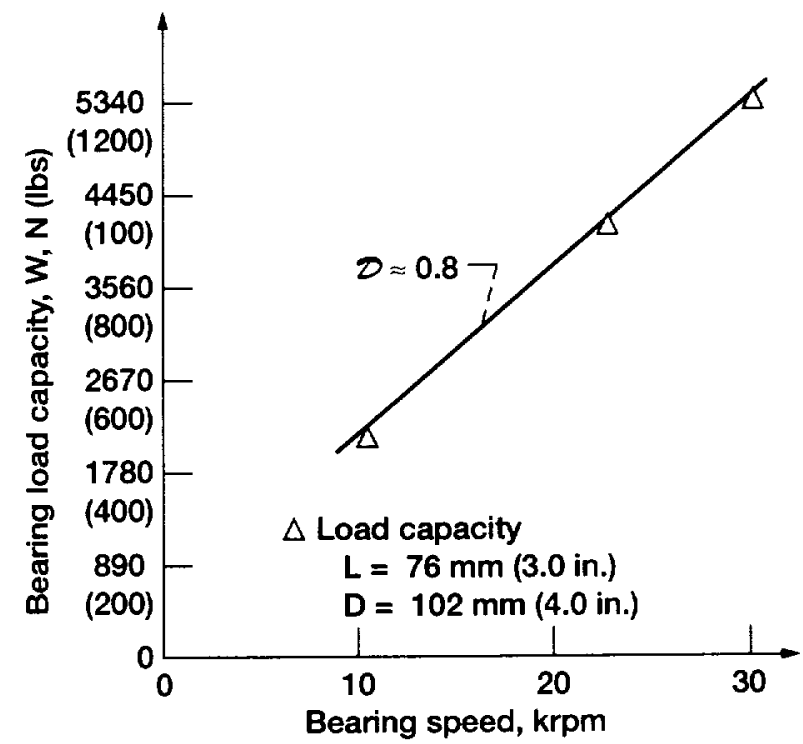

Figure 7.-Foil bearing load capacity for large, third generation foil air bearing. Data from reference 26.

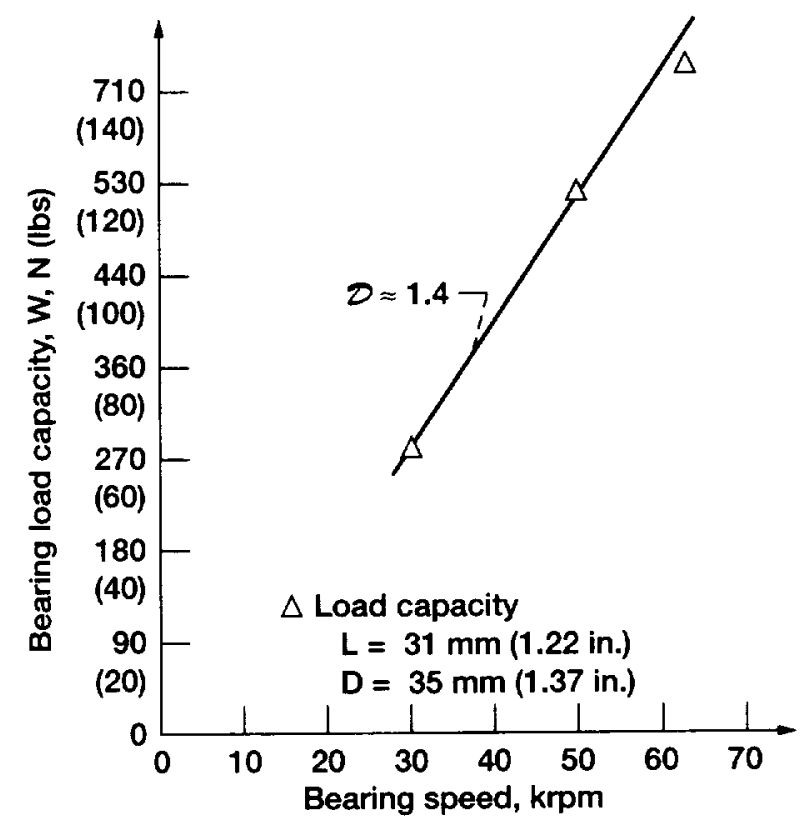

Figure 8.-Foil bearing load capacity for third generation bump foil bearing with axially and circumferentially varying bump foil design. Data from reference 8. 


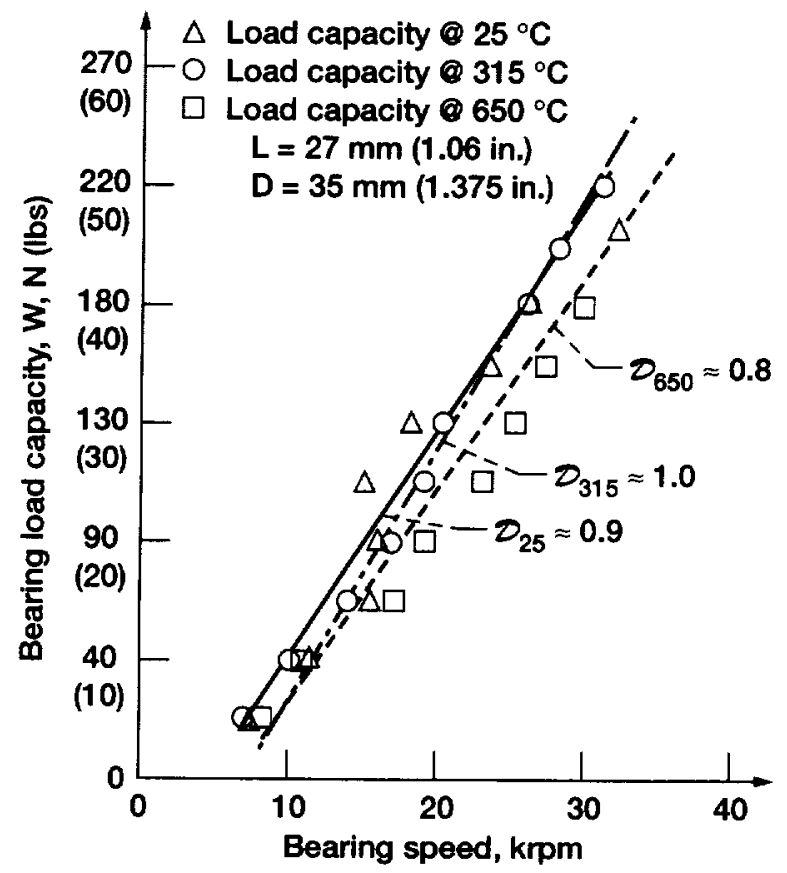

Figure 9.-Foil bearing load capacity for third generation bump foil bearing operating against PS304 coated shaft from 25 to $650^{\circ} \mathrm{C}$. Data from reference 7 . 

Public reporting burden for this collection of information is estimated to average 1 hour per response, including the time for reviewing instructions, searching existing data sources, gathering and maintaining the data needed, and completing and reviewing the collection of information. Send comments regarding this burden estimate or any other aspect of this collection of information, including suggestions for reducing this burden, to Washinglon Headquarters Services, Directorate for Davis Highway, Suite 1204, Arlington, VA 22202-4302, and to the Oftice of Management and Budget, Paperwork Reduction Project (0704-0188), Washington, DC 20503.

\begin{tabular}{|l|l|l|}
\hline 1. AGENCY USE ONLY (Leave blank) & $\begin{array}{r}\text { 2. REPORT DATE } \\
\text { October } 2000\end{array}$ & $\begin{array}{r}\text { 3. REPORT TYPE AND DATES COVERED } \\
\text { Technical Memorandum }\end{array}$ \\
\hline 4. TITLE AND SUBTITLE
\end{tabular}

Load Capacity Estimation of Foil Air Journal Bearings

for Oil-Free Turbomachinery Applications

6. AUTHOR(S)

Christopher DellaCorte and Mark J. Valco

\section{PERFORMING ORGANIZATION NAME(S) AND ADDRESS(ES)}

National Aeronautics and Space Administration

John H. Glenn Research Center

Cleveland, Ohio 44135-3191

and

U.S. Army Research Laboratory

Cleveland, Ohio 44135-3191

9. SPONSORING/MONITORING AGENCY NAME(S) AND ADDRESS(ES)

National Aeronautics and Space Administration

Washington. DC 20546-0001

and

U.S. Army Research Laboratory

Adelphi, Maryland 20783-1145
5. FUNDING NUMBERS

WU-523-18-13-00

11. SUPPLEMENTARY NOTES

Prepared for the International Joint Tribology Conference sponsored by the Society of Tribologists and Lubrication Engineers, Seattle, Washington, October 1-4, 2000. Christopher DellaCorte, NASA Glenn Research Center; and Mark J. Valco, U.S. Army Research Laboratory, NASA Glenn Research Center. Responsible person, Christopher DellaCorte, organization code 5960, 1-216-433-6056.

\begin{tabular}{|l|l} 
12a. DISTRIBUTIONAAVAILABILITY STATEMENT & 12b. DISTRIBUTION CODE
\end{tabular}

Unclassified - Unlimited

Subject Category: 07

Distribution: Nonstandard

Available electronically at http://gltrs.grc.nasa.gov/GLTRS

This publication is available from the NASA Center for AeroSpace Information, 1-301-621-0390.

13. ABSTRACT (Maximum 200 words)

This paper introduces a simple "Rule of Thumb" (ROT) method to estimate the load capacity of foil air journal bearings, which are self-acting compliant-surface hydrodynamic bearings being considered for Oil-Free turbomachinery applications such as gas turbine engines. The ROT is based on first principles and data available in the literature and it relates bearing load capacity to the bearing size and speed through an empirically based load capacity coefficient, D. It is show'n that load capacity is a linear function of bearing surface velocity and bearing projected area. Furthermore, it was found that the load capacity coefficient, $D$, is related to the design features of the bearing compliant members and operating conditions (speed and ambient temperature). Early bearing designs with basic or "first generation" compliant support elements have relatively low load capacity. More advanced bearings, in which the compliance of the support structure is tailored, have load capacities up to five times those of simpler designs. The ROT enables simplified load capacity estimation for foil air journal bearings and can guide development of new Oil-Free turbomachinery systems.

\section{SUBJECT TERMS}

Foil air bearings; Gas bearings; Journal bearings; Load capacity; Turbomachinery

15. NUMBER OF PAGES 20 16. PRICE CODE $\mathrm{A} 03$

\section{SECURITY CLASSIFICATION} OF REPORT

Unclassified

18. SECURITY CLASSIFICATION
OF THIS PAGE
Unclassified
19. SECURITY CLASSIFICATION OF ABSTRACT
Unclassified

Standard Form 298 (Rev. 2-89)

Prescribed by ANSI Std. Z39-18 298-102 
